\title{
ANALISIS FINANSIAL PENDAPATAN PETERNAK PLASMA BROILER OPEN HOUSE SYSTEM PT X DI KABUPATEN KEDIRI
}

\author{
Financial Analysis of Plasma Broiler Farmer Income Using Open House System \\ $P T X$ in Kediri
}

\author{
Niswatin Hasanah, Zaenal Fanani, Hari Dwi Utami \\ Pascasarjana Fakultas Peternakan, Universitas Brawijaya \\ Email: niswatinhasanah122@gmail.com
}

\section{INTISARI}

Penelitian ini bertujuan untuk menganalisis biaya produksi, penerimaan, pendapatan, efisiensi usaha ditinjau dari aspek finansial yang meliputi, R/C ratio dan BEP selama 6 periode produksi. Tiga puluh plasma dengan 3 skala usaha terdiri dari strata I (3.000 sampai 12.000 ekor), strata II (12.001 sampai 21.000 ekor) dan strata III (21.001 sampai 30.000 ekor). Hasil penelitian menunjukkan bahwa pendapatan tertinggi berada pada strata III periode 2 sebesar Rp2.217,00/kg bobot hidup dengan struktur biaya produksi Rp14.700,00/kg bobot hidup (dipengaruhi faktor pakan 75,7\% dan DOC 22,3\%) dan penerimaan sebesar Rp17.580,00 terdiri dari (dipengaruhi penjualan broiler 98,8\% dan bonus 0,57\%) untuk memproduksi $1 \mathrm{~kg}$ bobot hidup broiler. Pada strata III periode 2 yang paling efisien berdasarkan BEP harga mencapai Rp15.252,00/kg bobot hidup broiler dan aspek R/C ratio yakni 1,17.

Kata kunci : Broiler, Efisiensi, Finansial, Kemitraan

\section{ABSTRACT}

The study aimed to determine the production costs, revenue, earning, farming efisiency in terms of financial aspects. The farm efficiency can be obtained although $R / C$ ratio, and BEP price during 6 production period of 30 plasma according to 3 scale enterprises. Birds stratum divided into stratum I (3.000-12.000 birds, $n=16)$, stratum II $(12.001-21.000, n=11)$, stratum III (21.00130.000 birds, $n=3)$. The results indicated that the highest profit was strata III period 2 (Rp2,217.00/kg of live weight), the production cost was Rp14,700.00/ kg of live weight (influenced by feed factor $75.7 \%$ and DOC $22.3 \%$ ) and the revenue was Rp17,580.00 (consisted of affected by 98.8\% broiler sales and bonus 0,57\%) to produce 1 kilogram of live weight of broiler. In strata III period 2 the most efficient based on BEP price reached Rp15,252.00/kg broiler live weight and aspect $R / C$ ratio was 1.17 .

Keywords: Broiler, Efficiency, Financial, Partnership

\section{PENDAHULUAN}

\section{Latar Belakang}

Keberlanjutan usaha peternakan ditentukan oleh analisis finansial usaha. Kemampuan usaha peternakan dalam mengembangkan modal dapat diukur menggunakan parameter investasi antara lain mengembangkan modal awal dan meningkatkan keuntungan usaha pada masa yang akan datang. Suatu usaha dapat bertahan jika keuntungan yang diperoleh lebih besar daripada biaya yang dikeluarkan dimana semuanya itu harus diputuskan layak secara finansial (Fatah, 2004).

Salah satu kawasan di Jawa Timur yang memiliki potensi bagi pengembangan broiler adalah Kabupaten Kediri. Luas daerah 
Kabupaten Kediri 1.588,79 km² dengan jumlah penduduk sebanyak 1.140 .809 jiwa. Pemilihan kabupaten Kediri dilakukan karena sebagai daerah penghasil produksi ayam ras pedaging terbesar Jawa Timur diikuti kabupaten Malang dan kabupaten Lamongan. Data Statistik Dinas Peternakan Jawa Timur tahun 2013 mencatat bahwa jumlah produksi ayam pedaging sebesar $8.675 .890 \mathrm{~kg}$ dengan populasi sebesar 1.298 .976 ekor. Pola kemitraan dalam usaha broiler meliputi perusahaan sebagai inti dan peternak sebagai plasma yang terikat oleh kontrak.

Untuk itu analisis finansial penting diketahui pada peternakan plasma broiler kemitraan open house system di PT. X, Kabupaten Kediri.

\section{Tujuan Penelitian}

1. Menganalisis biaya produksi, penerimaan, dan pendapatan usaha peternakan broiler selama 6 periode produksi.

2. Menganalisis kelayakan usaha ditinjau dari aspek finansial yang meliputi $\mathrm{R} / \mathrm{C}$ ratio dan BEP selama 6 periode produksi.

\section{MATERI DAN METODE}

\section{Penentuan Lokasi}

Lokasi pengambilan data dilakukan pada 1 inti kemitraan dengan 30 plasma di Kabupaten Kediri. PT. X adalah salah satu perusahaan kemitraan yang bergerak dibidang usaha broiler yang juga menggunakan sistem kontrak antara perusahaan kemitraan (inti) dan mempunyai jumlah peternakan (plasma) terbanyak di Jawa Timur.

\section{Pengambilan Sampel}

Pengambilan sampel menggunakan Purposive sampling (Sugiono, 2010), yaitu pengambilan sampel berdasarkan kriteria tertentu, kemudian sampel yang diperoleh di stratifikasikan menjadi 3 strata yaitu : strata I (3.000 sampai 12.000 ekor), strata II (12.001 sampai 21.000 ekor), dan strata III (21.001 sampai 30.000 ekor).

\section{Analisis Data}

\section{Biaya produksi}

Biaya produksi dihitung menurut Soekartawi (2003).

\begin{tabular}{l}
\hline TC = TFC + TVC \\
Keterangan: \\
TC = Total Cost atau biaya total (Rp) \\
TFC = Total Fixed Cost atau total biaya tetap \\
(Rp) \\
TVC = Total Variabel Cost atau total biaya tidak \\
tetap (Rp)
\end{tabular}

\section{Penerimaan}

Penerimaan dihitung menurut Soekartawi (2002).

TR = Pq $\times$ Q

Keterangan:

$\mathrm{TR}=$ Total Revenue atau penerimaan total (Rp)

$\mathrm{Pq}=$ Price of quality atau harga produk satuan (Rp)

Q = Quantity atau produksi (ekor)

\section{Pendapatan}

Pendapatan adalah selisih antara total penerimaan dengan total biaya yang telah dikeluarkan dihitung menurut Ahyari (2007). 


$$
\ldots \mathrm{TR}-\mathrm{TC}
$$

Keterangan:

$\pi \quad=$ Keuntungan (Rp)

$\mathrm{TR}=$ Total Revenue atau total penerimaan usaha broiler (Rp)

$\mathrm{TC}=$ Total Cost atau biaya total (Rp)

\section{Analisis finansial}

Analisis finansial yang dihitung adalah BEP harga, BEP produk, BEP ekor, dan R/C ratio.

$\mathrm{BEPharga}=\frac{\text { Biaya Produksi Total Usaha Broiler }(\mathrm{Rp})}{\text { Hasil Panen Usaha Broiler }(\mathrm{kg})}$

$\mathrm{BEP}_{\text {produk }}=\frac{\overline{\text { maya Produksi Total Usaha Brailet }}}{\text { Harga Jual per Kg Bobot Hitup }}$

$$
\mathrm{BEP}_{\text {ekor }}=\frac{\text { BEP produk }}{\text { Bobot Hidup per ekor }}
$$

\section{$\mathrm{R} / \mathrm{C}$ ratio}

Suatu usaha dikatakan menguntungkan jika perbandingan antara Revenue dan Cost (R/C) bernilai lebih besar dari satu. R/C ratio yaitu perbandingan antara penerimaan dengan biaya menurut Soekartawi (2003).

\section{HASIL DAN PEMBAHASAN}

\section{Biaya Produksi}

Biaya produksi tertinggi terdapat pada biaya pakan dengan persentase pada strata I, II, dan III berturut-turut sebesar 74,62\%, 75,09\%, dan 75,47\% (Tabel 1). Menurut Yunus (2009) bahwa dalam usaha kemitraan broiler, proporsi biaya pakan sebesar 73,54\% dari total biaya. Hasil dari strata I menunjukkan lebih efisien dibandingkan strata II dan III dengan selisih $~ 0,38 \%$ sampai $0,85 \%$

Perbedaan persentase biaya pakan pada masing-masing strata disebabkan adanya perbedaan jumlah pakan yang dikonsumsi. Hal ini relevan dengan (Ismail et al., 2013) biaya pakan mengambil proposi 60 sampai 70\% dari total biaya. Jumlah penggunaan pakan merk S10; S11; S11GJ; S-00 dan S12 yang berbedabeda tiap merk pakan memiliki harga yang berbeda pula, tergantung jenis bentuk pakan, kandungan nutrisi, dan kualitas.

\section{Penerimaan}

Penerimaan dari penjualan broiler memberikan kontribusi terbesar sebesar $98,65 \%$ pada strata I, $98,94 \%$ pada strata II dan $98,99 \%$ pada strata III dari $100 \%$ jumlah persentase penerimaan. Semakin besar populasi ayam yang dimiliki maka semakin besar pula penerimaan yang diterima oleh peternak. Hal serupa disampaikan Sahri (2006) jumlah kepemilikan ternak akan menentukan penerimaan yang akan diperoleh.

\section{Pendapatan}

Hasil analisis pendapatan dari variasi pendapatan peternak kemitraan PT. X Kediri. Salah satu hasil perhitungan pendapatan dapat diinterprestasikan bahwa setiap ekor penjualan ayam pada strata I akan memperoleh pendapatan sebesar Rp3.248,00 atau Rp1.756,00/kg bobot hidup (Tabel 3). Sesuai dengan pernyataan (Siregar 2009) bahwa semakin rendah nilai feed consumption ratio (FCR), semakin kecil jumlah biaya yang 
harus dikeluarkan untuk membeli pakan, ayam yang berbeda dimana harga panen tiap Perbedaan juga disebabkan oleh bobot panen bobot badan berbeda.

Tabel 1. Struktur Rata-Rata Biaya dan Pendapatan Produksi Selama 6 Periode

\begin{tabular}{|c|c|c|c|c|c|c|c|c|c|}
\hline \multirow[b]{2}{*}{ Uraian } & \multicolumn{3}{|c|}{ Strata! } & \multicolumn{3}{|c|}{ Strata II } & \multicolumn{3}{|c|}{ Stratall } \\
\hline & Jumlah(Rp) & $\begin{array}{l}\text { Per Kg bobat } \\
\text { hidup }(R p)\end{array}$ & (\%) & fumlah(Rp) & $\begin{array}{l}\text { Per Kg bobot } \\
\text { hidup (Rp) }\end{array}$ & (\%) & fumlah (Rp) & $\begin{array}{l}\text { Per Kg bobat } \\
\text { hidup (BD) }\end{array}$ & (\%) \\
\hline \multicolumn{10}{|l|}{ Biaya Tetap } \\
\hline Penyusutan kandang & 5.443 .750 & 86.23 & 0.55 & 8.247 .273 & 58.47 & 0.38 & 11.600 .000 & 49,00 & 0.33 \\
\hline Penyusutan gudang & 572.500 & 9,07 & 0,06 & 844.545 & 5.99 & 0.04 & 220.000 & 9,38 & 0.06 \\
\hline Penyusutan peralatan & 2.950 .000 & 46.73 & 0,30 & $5,760,727$ & 40,84 & 0.26 & 5.760 .000 & 24,42 & 0.17 \\
\hline Sevva lahan & 2.995 .933 & 47,3 & 0.30 & 6.536 .354 & 46,69 & 0.30 & $11.930,000$ & 50.61 & 0,34 \\
\hline Gajt karyzwan & 7.050 .000 & 111.67 & 0.71 & 13.200 .000 & 93,58 & 0.60 & 25.721 .934 & 108.66 & 0.73 \\
\hline fumlah & 19.002 .1888 & 301 & & 34.638 .909 & 246 & & 57.301 .984 & 242 & \\
\hline \multicolumn{10}{|l|}{ Biaya Tidak tetap } \\
\hline DOC & 223.258 .750 & 3.535 .80 & 22.57 & $495,390.931$ & 3.51100 & 22.60 & 773.496 .000 & $3.267,56$ & 22.10 \\
\hline Pakan & $738.136,745$ & $11.692,14$ & 74,62 & $2.646,021.312$ & 11.668 .86 & 75.09 & 2.641 .850 .000 & 11.160 .23 & 75,47 \\
\hline Obat dan vakerin & 7.173 .637 & 113,63 & 0,73 & 13.915 .561 & 98,65 & 0.63 & 25.721 .994 & 108,66 & 0.73 \\
\hline Listrik dan air & 1.655 .625 & 26.23 & 0.17 & 2.151 .364 & 15,25 & 0,10 & 4.060 .000 & 17,15 & 0.12 \\
\hline Jumlah & 970.184 .759 & 15.368 & & 2.157 .487 .168 & 15,295 & & 3.445 .127 .984 & 14.554 & \\
\hline Jumlah Biaya Produksi & 989.136 .946 & 15.669 & 100.00 & 2.192.126.077 & 15540 & 100.00 & 3.500 .508 .032 & 14.796 & 100.00 \\
\hline Penjualan ayam & $1.035,178.573$ & 17.189 & 98,65 & $1085,178,573$ & 17,116 & 95,94 & 3.992 .378 .640 & 17.365 & 98,99 \\
\hline Sekam bekae + manure & 3.270 .313 & 52 & 0,30 & $3,270,313$ & 51 & 0.30 & 11.100 .000 & 53 & 0.30 \\
\hline Sakpakan & 1.968 .365 & 31 & 0.18 & $1,968.365$ & 31 & 0.18 & 8.600 .000 & $\$ 6$ & 0.21 \\
\hline Bonus FCR & 4.952 .775 & 78 & 0,45 & 4.952 .775 & 79 & 0.32 & 3.720 .000 & 82 & 0,46 \\
\hline Bonus Mortalitas & 867.334 & 14 & 0,08 & 867.384 & 14 & 0.09 & .4 .844 .262 & 20 & 0.12 \\
\hline Transport pengantar dok & 735.225 & 12 & 0.07 & 735.225 & 10 & 0.06 & 2.538 .000 & 13 & 0.08 \\
\hline Diskon pakan & $3,041,059$ & $48^{\circ}-x-3-1$ & 0.28 & $3.041,058$ & 22 & 0,13 & 2.019 .435 & 52 & 0.29 \\
\hline Jumlah Penerimasn & 1.100 .013 .692 & 17.424 & 100.00 & 1.100 .013 .692 & 17.299 & 100.00 & 4.025 .200 .337 & 17570 & 100,00 \\
\hline Pendapatan & 110.826 .746 & 3.248 & 1.756 & 248.053 .546 & 3,295 & 1,750 & 524.692 .255 & 3.545 & 2.217 \\
\hline
\end{tabular}

Perbedaan penerimaan dipengaruhi oleh menentukan besarnya skala produksi yang mortalitas, serta pencapaian standar FCR berdampak pada total penerimaan yang dimana terdapat bonus selisih FCR dan semakin meningkat pula. Besarnya total semakin kecil nilai FCR yang dicapai, maka keuntungan disatu sisi juga dipengaruhi oleh semakin efisien. Hal ini sesuai dengan faktor penerimaan selain faktor biaya pernyataan Siregar (2009) bahwa semakin produksi di sisi lainnya. Hal ini sesuai dengan rendah nilai FCR, semakin kecil jumlah biaya pendapat Prawirokusumo (2001) yang yang harus dikeluarkan untuk membeli pakan, menyatakan bahwa pendapatan usaha tani sebaliknya semakin tinggi nilai FCR, semakin dipengaruhi oleh penerimaan usaha tani dan besar jumlah biaya yang harus dikeluarkan iaya produksi. Pambudi et al. (2013) untuk membeli pakan. Perbedaan juga menambahkan bahwa semakin besar disebabkan oleh bobot panen ayam yang keuntungan yang diperoleh suatu usaha maka berbeda dimana harga panen tiap bobot badan akan semakin efisien usaha tersebut dan berbeda. Semakin besar skala produksi akan semakin layak untuk dikembangkan. 
Tabel 4. Analisis Break Even Point Selama 6 Periode Produksi

\begin{tabular}{lccccccc}
\hline Strata & $\begin{array}{c}\text { Biaya Produksi } \\
\text { (Rp) }\end{array}$ & $\begin{array}{c}\text { Bobot } \\
\text { Panen 1 } \\
\text { Tahun (kg) }\end{array}$ & $\begin{array}{c}\text { Harga } \\
\text { Ayam } \\
\text { (Rp/kg } \\
\text { BB) }\end{array}$ & $\begin{array}{c}\text { BB } \\
\text { Per } \\
\text { Ekor }\end{array}$ & $\begin{array}{c}\text { BEP } \\
\text { harga } \\
\text { (Rp) }\end{array}$ & $\begin{array}{c}\text { BEP } \\
\text { produk } \\
\text { (kg) }\end{array}$ & $\begin{array}{c}\text { BEP ekor } \\
\text { (ekor) }\end{array}$ \\
\hline I & 989.186 .946 & 63.131 & 17.192 & 1,84 & 15.700 & 57.545 & 31.122 \\
II & 2.192 .126 .077 & 141.061 & 17.300 & 1,87 & 15.537 & 128.159 & 68.388 \\
III & 3.500 .508 .082 & 236.720 & 17.230 & 1,85 & 14.906 & 207.714 & 112.278 \\
\hline
\end{tabular}

\section{Break Even Point}

BEP harga pada strata I adalah sebesar Rp15.700,00/kg bobot hidup dengan rata-rata bobot panen $1,84 \mathrm{~kg} / \mathrm{ekor}$, pada strata II adalah sebesar Rp15.537,00/kg bobot hidup dengan rata-rata bobot panen $1,87 \mathrm{~kg} /$ ekor dan pada strata III adalah sebesar Rp14.906,00/kg bobot hidup dengan rata-rata bobot panen 1,85 kg/ekor yang artinya pada harga penjualan tersebut peternak tidak akan mengalami kerugian atau harga tersebut merupakan dasar harga minimal yang boleh ditetapkan, sementara harga kontrak yang diberikan pihak inti adalah diatas harga BEP, yaitu sebesar Rp17.190,00/kg bobot hidup untuk panen dengan bobot ayam 1,88 $\mathrm{kg}$ sampai 1,99 kg yang artinya harga kontrak yang diberikan inti telah di atas harga BEP sehingga terdapat keuntungan yang diperoleh peternak dari penjualan ayam. Hasil perhitungan BEP lebih tinggi dibanding dengan hasil penelitian Nugroho (2013) menunjukkan bahwa nilai BEP harga peternak skala menengah sebesar Rp14.452,00/kg dan peternak skala kecil sebesar Rp13.764,00/kg dengan rentang harga kesepakatan mulai Rp14.640,00/kg sampai Rp14.720,00/kg.

Perbedaan ini disebabkan oleh adanya perbedaan tahun panen yang berpengaruh pada kesepakatan harga satuan produksi ternak dimana pada tahun 2014, kesepakatan harga lebih tinggi dibanding dengan kesepakatan harga kontrak pada tahun 2013. BEP produk pada strata I adalah sebesar $57.545 \mathrm{~kg}$ bobot hidup, pada strata II adalah sebesar $128.159 \mathrm{~kg}$ dan pada strata III adalah sebesar $207.714 \mathrm{~kg}$ bobot hidup yang artinya pada minimal total keseluruhan bobot panen selama 1 tahun tersebut, peternak tidak mengalami kerugian.

Hasil tersebut lebih kecil dari rata-rata bobot panen yang dicapai, yaitu $63.131 \mathrm{~kg}$ pada strata I, $141.061 \mathrm{~kg}$ pada strata II dan $236.720 \mathrm{~kg}$ pada strata III. Sedangkan pada BEP ekor pada strata I, strata II, strata dan III secara berturut- turut adalah sebesar 31.122 ekor, 68.388 ekor, dan 112.278 ekor pertahun yang menunjukkan bahwa pada jumlah minimal kapasitas pemeliharaan tersebut dengan bobot panen 1,84 kg pada strata I, pada strata II bobot panen per ekor 1,87 kg, pada strata III 1,85 kg, peternak tidak akan mengalami kerugian. Jumlah hasil BEP ekor lebih kecil dari pada jumlah kapasitas dimiliki peternak, menandakan peternak memperoleh keuntungan dikarenakan kapasitas pemeliharaan yang dimiliki diatas nilai BEP ekor. 


\section{Analisis R/C Ratio}

Hasil perhitungan $\mathrm{R} / \mathrm{C}$ ratio dari usaha kemitraan PT. X Kediri memiliki nilai R/C ratio rata-rata $>1$ sehingga dapat diartikan bahwa usaha tersebut efisien dan menguntungkan untuk semua strata. Hal ini sesuai dengan pernyataan Soekartawi (2002) bahwa suatu usaha dikatakan efisien jika $\mathrm{R} / \mathrm{C}$ ratio $>1$ menunjukkan usaha tersebut menguntungkan. Nilai $\mathrm{R} / \mathrm{C}$ ratio rata-rata peternak kemitraan
PT. X Kediri yang terbesar pada strata III, yaitu 1,15. Semakin besar kapasitas pemeliharaan, biaya produksi yang digunakan semakin efisien. Nilai R/C ratio kemitraan broiler PT. X Kediri sama besarnya dengan hasil penelitian Ismail (2013) sebesar 1,12. Nilai $\mathrm{R} / \mathrm{C}$ ratio dapat ditingkatkan dengan efisiensi biaya produksi dan meningkatkan hasil produksi. Profil setiap periode pada tiga strata disajikan pada Gambar 2.

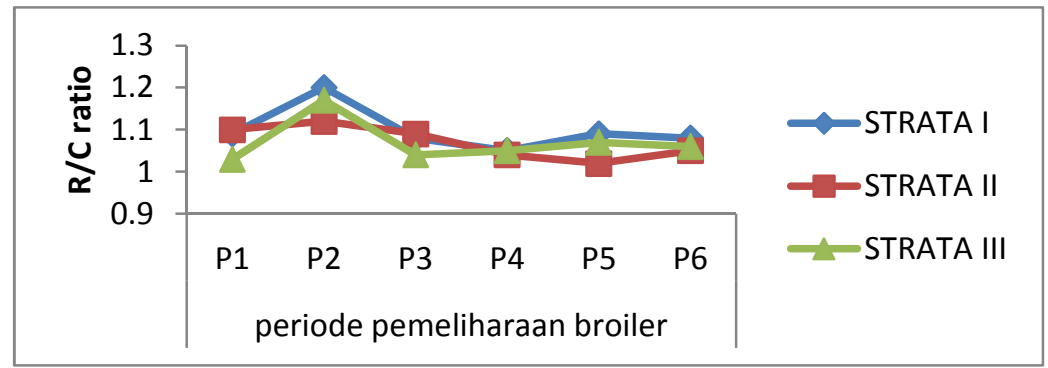

Gambar 2. R/C Ratio selama 6 periode pemeliharaan

\section{KESIMPULAN DAN SARAN}

\section{Kesimpulan}

Penelitian tentang Analisis Finansial Peternakan Plasma Broiler Kemitraan Open House System PT. X di Kabupaten Kediri pada 6 periode produksi dalam 3 strata, strata I (penguasaan ternak 3000 - 12.000 ekor, ratarata 5.688 ekor, $\mathrm{n}=16$ ), strata II (penguasaan ternak 12.001-21.000 ekor, rata-rata 12.545 ekor, $\mathrm{n}=11$ ) dan strata III (penguasaan ternak 21.001-30.000 ekor, rata-rata 24.667 ekor, $\mathrm{n}=3$ ) menunjukkan bahwa :

1. Strata III periode 2 adalah keuntungan tertinggi sebesar Rp2.217,00 dengan struktur biaya produksi Rp14.700,00 (pakan 75,7\% dan DOC 22,3\%) dan penerimaan sebesar Rp17.580,00 terdiri dari (penjualan broiler 98,8\% dan bonus 0,57\%) untuk memproduksi 1 kilogram bobot hidup broiler.

2. Strata III periode 2 yang paling efisien berdasarkan BEP harga mencapai Rp15.252,00/kg bobot hidup broiler dan aspek R/C ratio yakni 1,17.

\section{Saran}

1. Sebaiknya peternak melakukan perbaikan manajemen pemberian pakan sehingga lebih efisien.

2. Disarankan bagi peternak untuk meningatkan produksi usaha melelui peningkatan jumlah populasi ternak sehingga usaha lebih efisien. 


\section{DAFTAR PUSTAKA}

Ahyari, A. 2007. Pengendalian Produksi. Jilid 2 Edisi 4. Badan Penerbit Fakultas Ekonomi. Universitas Gadjah Mada. Yogyakarta.

Dinas Peternakan Kabupaten Kediri. 2013. Laporan Tahunan Keadaan Ternak di Kabupaten Kediri.

Fatah. 2004. Evaluasi Proyek: Aspek Finansial Pada Proyek Mikro. CV Asona. Jakarta.

Ismail, I., H.D. Utami, B. Hartono. 2013. Analisa ekonomi usaha peternakan broiler yang menggunakan dua tipe kandang berbeda. Jurnal Ilmu-ilmu Peternakan. 23(3): 11-16.

Nugroho. 2013. Analisis Kinerja Finansial Usaha Peternakan Broiler Skala Kecil dan Menengah pada Kemitraan "PT. Sinar Sarana Sentosa" Kabupaten Malang. Skripsi. Fakultas Peternakan. Universitas Brawijaya. Malang.

Pambudi, T.R. Edy, O. dan Hidayat, N.N. 2013. Analisis keuntungan dan rentabilitas usaha ayam niaga pedaging. Jurnal Ilmiah Peternakan 1(3): 1128 -1135

Prawirokusumo, S. 2001. Ilmu Usaha Tani. Rajawali. Jakarta.

Sahri. 2006. Paket Ekonometrika Perikanan. Fakultas Perikanan dan Ilmu Kelautan. Universitas Brawijaya. Malang.

Siregar. 2005. Studi Kelayakan Bisnis (Edisi 3). Teknik Menganalisis Kelayakan Rencana Bisnis Secara Komperhensi. Gramedia Pustaka Utama. Jakarta.

Sudjana. 2002. Teknik Analisis Regresi dan Korelasi. Tarsito. Bandung.

Sugiono. 2010. Metode Penelitian Kuantitatif Kualitatif, dan R\&D. Alabeta. Bandung.

Soekartawi. 2002. Analisis Usaha Tani. UI Press. Jakarta.

Soekartawi. 2003. Teori Ekonomi Produksi dengan Pokok Bahasan Analisis Fungsi Cobb-Douglas. Jakarta: Raja Grafindo Persada.

Yunus, R. 2009. Analisis Efisiensi Produksi Usaha Peternakan Ayam Ras Pedaging Pola Kemitraan dan Mandiri di Kota Palu Provinsi Sulawesi Tengah. http://eprints.undip.ac.id/18874/1/Rit a_Yunus.pdf Diakses tanggal 13 Maret 2014. 